\title{
CREATIVE STRATEGY IN PRODUCTION OF PROMOTION VIDEO FOR THE RATTAN TOURISM VILLAGE OF TRANGSAN
}

\author{
Daniel A Morgana ${ }^{1}$, Sigit Rizal H. ${ }^{2}$, Firdana Bilankawa ${ }^{3}$, Alpin Ramadhian ${ }^{4}$, dan Nur \\ Rahmat Ardi Candra D.A . \\ ${ }^{1}$ Insitut Seni Indonesia (ISI) Surakarta \\ 2 Insitut Seni Indonesia (ISI) Surakarta \\ ${ }^{3}$ Insitut Seni Indonesia (ISI) Surakarta \\ ${ }^{4}$ Insitut Seni Indonesia (ISI) Surakarta \\ ${ }^{5}$ Insitut Seni Indonesia (ISI) Surakarta \\ E-mail: danielmorgana28@gmail.com
}

\begin{abstract}
One aspect that affects the speed of development of a tourist village is the promotion of the village. Promotion of village tourism is very important especially for villages that are pioneering. Village promotion can be carried out by internal elements who carry out promotions and information intensively. Therefore, it is necessary to involve the village youth group "Susilo Bhakti" of Trangsan Village. Research methods with a focus on creative strategies implemented in the preproduction, production and post-production stages. The results of the study showed that 1) village youth group were able to make creative videos that highlighted the uniqueness of the Rattan Tourism Village of Trangsan; 2) Strategy in the preproduction stage is to emphasize the importance in determining ideas and concepts that are the main theme, 3) Strategy in the production phase is to focus on understanding about the several types of shooting of local village tourism objects, and 4) Strategy in the postproduction stage is focus on image editing and publication on social media Youtube and Instagram.
\end{abstract}

Keywords: Strategt, creative video, promotion, dan Rattan Tourism Village of Trangsan

\begin{abstract}
ABSTRAK
Salah satu aspek yang mempengaruhi cepat atau lambatnya perkembangan desa wisata adalah aspek promosi desa tersebut. Promosi desa wisata sangat penting terutama bagi desa yang sedang merintis. Promosi desa dapat dilakukan oleh unsur internal yang melakukan promosi dan informasi dengan gencar. Maka dari itu, perlu melibatkan kelompok pemuda desa "Susilo Bhakti" Desa Trangsan. Metode penelitian dengan fokus pada strategi kreatif yang dilaksanakan pada tahap praproduksi, produksi, dan pascaproduksi. Hasil studi menunjukkan bahwa: 1) pemuda karang taruna mampu membuat video kreatif yang mengangkat kekhasan Desa Wisata Rotan Trangsan; 2) Strategi dalam tahap praproduksi menekankan pentingnya dalam penentuan ide dan konsep yang menjadi tema utama, 3) Strategi dalam tahap produksi fokus pada pemahaman tentang beberapa tipe pengambilan gambar terhadap objek-objek wisata desa setempat, dan 4) Strategi dalam tahap pascaproduksi fokus pada penyuntingan gambar dan publikasi ke media sosial Youtube dan Istagram.
\end{abstract}

Kata kunci: Strategi, video kreatif, promosi, dan Desa Wisata Rotan Trangsan

\section{PENDAHULUAN}

Upaya peningkatan kesejahteraan masyarakat, salah satu yang harus diperhatikan yakni dari sektor pariwisata. 
Sektor pariwisata di Indonesia dapat dijadikan andalan sebagai sumber penerimaan daerah dan negara. Pengembangan pariwisata tidak harus menciptakan tempat wisata yang besar dengan pengunjung dalam jumlah banyak dari berbagai penjuru dunia. Justru, pariwisata dapat dimulai dari desa sebagai satuan unit terkecil dan dekat dengan rakyat. Perkembangan zaman yang pesat membuat banyak daerah memiliki strategi dan cara bagaimana menonjolkan potensi daerahnya masing-masing. Desa harus cerdas dan jeli dalam melihat potensi dan menerapkan strategi serta manajemen dalam pengelolaan potensi lokalnya yang dikemas ke dalam format desa wisata. Desa wisata didefinisikan secara beragam. Salah satu pemahaman tentang wisata desa yang dikemukakan oleh D. Winarni Suyanti adalah suatu bentuk lingkungan yang memiliki ciri khas khusus, baik alam maupun budaya yang sesuai dengan tuntutan wisatawan, dimana mereka dapat mengenal, mengakhayati, dan mempelajari kekhasan desa beserta segala daya tariknya (Suyanti, 2013).

Salah satu unsur yang menentukan cepat atau lambatnya pengembangan desa wisata adalah promosi desa tersebut. Promosi adalah kegiatan untuk mengarahkan seseorang atau organisasi kepada tindakan yang menciptakan pertukaran dan pemasaran (Ri'aeni, 2015). Promosi desa wisata sangat penting terutama bagi desa yang sedang merintis. Promosi desa dapat berasal dari internal desa dengan gencar melakukan promosi dan penyebaran informasi dari mulut ke mulut. Maka dari itu, dibutuhkan media untuk mempromosikan desa wisata. Jika desa wisata sudah terpromosikan dengan baik maka tinggal memperbaiki aspek lain seperti fasilitas umum, peningkatan akses, dan lain-lain. Kegiatan promosi perlu juga melibatkan pemuda remaja, salah satunya adalah pemuda remaja yang tergabung dalam organisasi karang taruna.

$$
\text { Karang taruna Susilo Bhakti }
$$
merupakan salah satu dari sekian banyak karang taruna di Indonesia yang berada di Desa Trangsan, Kecamatan Gatak, Kabupaten Sukoharjo. Pada desa tersebut, sebagian besar masyarakatnya berprofesi sebagai pengrajin dan penjalin rotan, oleh karena itu, mulai tahun 2016 lalu, Desa Trangsan telah diresmikan sebagai Desa Wisata Rotan. Salah satu permasalahan saat ini yaitu terbatasnya sumber daya untuk membantu mempublikasikan dan menyebarluaskan serta mempromosikan Desa Wisata Rotan Trangsan, sehingga desa wisata tersebut kurang dikenal oleh masyarakat luas. Sementara itu, peranan dari pihak pemuda pun masih sangat minim dalam turut mengembangkan Desa Wisata Rotan Trangsan.

Maka dari itu, program ini berencana memberikan pelatihan kepada pemuda remaja di karang taruna "Susilo Bhakti" 
dalam bagaimana cara membuat konten kreatif (foto-video) sebagai media untuk mempromosikan Desa Wisata Rotan Trangsan, sehingga Desa Wisata Rotan Trangsan bisa dikenal oleh masyarakat luas, tidak hanya di daerah sekitarnya saja namun juga seluruh Indonesia atau bahkan sampai ke mancanegara. Alasan lain yang melatarbelakangi pembuatan program ini yaitu untuk membuka peluang bisnis bagi pemuda remaja yang ingin menekuninya, misalnya membuka jasa pembuatan video kreatif, wedding, photobooth, sinematic, short movie, video shoting, dan lain-lain.

\section{TINJAUAN PUSTAKA}

Tipologi desa wisata didasarkan atas karakteristik sumber daya dan keunikan yang dimilikinya dapat dikelompokkan dalam 4 (empat) kategori (Deparnas, 2005), yaitu:

Pertama, desa wisata berbasis keunikan sumber daya budaya lokal (adat tradisi kehidupan masyarakat, artefak budaya, dan sebagainya) sebagai daya tarik wisata utama, yaitu wilayah pedesaan dengan keunikan berbagai unsur adat tradisi dan kekhasan kehidupan kesehantan masyarakat yang melekat sebagai bentuk budaya masyarakat pedesaan, baik terkait dengan aktivitas mata pencaharian, religi maupun bentuk aktivitas lainnya.

Kedua, desa wisata berbasis keunikan sumber daya alam sebagai daya tarik utama (pegunungan, agro atau perkebunan dan pertanian, pesisir-pantai, dan sebagainya), yaitu wilayah pedesaan dengan keunikan lokasi yang berada di daerah pegunungan, lembah, pantai, sungai, danau dan berbagai bentuk bentang alam yang unik lainnya, sehingga desa tersebut memiliki potensi keindahan view dan lanskap untuk menarik kunjungan wisatawan.

Ketiga, desa wisata berbasis perpaduan keunikan sumber daya budaya dan alam sebagai daya tarik utama, yaitu wilayah pedesaan yang memiliki keunikan daya tarik yang merupakan perpaduan yang kuat antara keunikan sumber daya wisata budaya (adat tradisi dan pola kehidupan masyarakat) dan sumber daya wisata alam.

Keempat, desa wisata berbasis keunikan aktivitas ekonomi kreatif (industri kerajinan, dan sebagainya) sebagai daya tarik wisata utama, yaitu wilayah pedesaan yang memiliki keunikan dan daya tarik sebagai tujuan wisata melalui keunikan aktivtas ekonomi kreatif yang tumbuh dan berkembang dari kegiatan industri rumah tangga masyarakat lokal, baik berupa kerajinan, maupun aktivitas kesenian yang khas

Perhatian unsur kelokalan dan keaslian seperti arsitektur bangunan, pola lanskap dan material yang digunakan dalam pembangunan haruslah menjadi faktor utama untuk mengangkat ciri khas desa sehingga dapat mencerminkan 


\section{CAPTURE}

kelokalan dan keaslian wilayah setempat. Bahan-bahan atau material yang digunakan untuk bangunan rumah, interior, peralatan makan, minum dan fasilitas lainnya, hendaknya memberikan nuansa yang alami dan menggambarkan unsur kelokalan dan keasliannya. Bahan-bahan seperti kayu, gerabah, bambu dan sirap serta material alami lainnya hendaknya mendominasi suasana, sehingga menyatu dengan lingkungan alami sekitarnya. Penggunaan bahan-bahan tersebut selain meningkatkan daya tarik desa yang bersangkutan juga sesuai dengan konsep dasar lingkungan (Yuty, 1997).

Pemberdayaan masyarakat sekitar desa wisata merupakan kegiatan yang penting dalam pengembangan sebuah desa wisata. Pengembangan wisata sebagai pengejawantahan dari konsep pariwisata inti rakyat mengandung arti bahwa masyarakat desa memperoleh manfaat sebesar-besarnya dalam pengembangan pariwisata. Masyarakat terlibat langsung dalam kegiatan pariwisata dalam bentuk pemberian jasa dan pelayanan yang hasilnya dapat meningkatkan pendapatan masyarakat di luar aktivitas mereka sehari-hari. Beberapa bentuk keterlibatan masyarakat tersebut adalah penyediaan fasilitas akomodasi berupa rumah-rumah penduduk yang dijadikan konsep homestay, penyediaan kebutuhan konsumsi wisatawan, pemandu wisata, penyediaan transponasi lokal seperti andong atau dokar, kuda, pertunjukan kesenian, dan lain sebagainya. Salah satu aspek yang mempengaruhi cepat atau lambatnya perkembangan desa wisata adalah aspek promosi desa tersebut. Promosi adalah kegiatan untuk mengarahkan seseorang atau organisasi kepada tindakan yang menciptakan pertukaran dan pemasaran. Promosi desa wisata sangat penting terutama bagi desa wisata yang sedang merintis. Promosi desa dapat berasal dari internal desa itu sendiri dalam melakukan strategi promosi dan informasi yang merupakan satu kegiatan yang menyeluruh dan berkesinambungan untuk mengenalkan keunikan desa kepada masyarakat lebih luas.

\section{METODE}

Strategi berasal dari bahasa
Yunani kuno yang berarti 'seni berperang'. Suatu strategi mempunyai dasar-dasar atau skema untuk mencapai sasaran yang dituju. Jadi, pada dasarnya strategi merupakan alat untuk mencapai tujuan.

Dalam menyajikan sebuah program yang berisikan informasi penting diperlukan tahapan-tahapan yang tak kalah pentingnya juga. Strategi tersebut diwujudkan dalam sebuah perencanaan, produksi, eksekusi, pengawasan, dan evaluasi program (Rahayu \& Sugihartono, 2018). Sedangkan, menurut Kamus Besar Bahasa Indonesia, strategi adalah 
rencana cermat tentang suatu kegiatan guna meraih target atau sasaran (Salim \& Salim, 1993).

Strategi merupakan tahap awal bagi sebuah organisasi atau tim kerja dan di dalamnya terdapat langkahlangkah atau tindakan dalam rangka pencapaian tujuan yang telah ditentukan. Garansi keberhasilan sebuah strategi, maka diperlukan adanya kebijakan yang berkaitan dengan pedoman pelaksanaan, metode kerja, prosedur dan peraturan-peraturan. Selain itu, dalam pelaksanaan strategi dibutuhkan stimulan untuk memberikan dorongan dan memotivasi bagi organisasi atau tim kerja tersebut dalam menyukseskan pencapaian sasaran yang dikehendaki bersama.

Proses pelaksanaan sebuah
produksi program atau kegiatan
bersama dalam satu tim kerja
pengorganisasiannya melakukan
beberapa tahapan penting yang
biasannya disebut dengan istilah
Standart Operating Procedure (SOP).
Tahapan-tahapan dalam pelaksanaan
SOP khususnya dalam produksi program-
program audio visual meliputi praproduksi
(preproduction), produksi (production) dan
pasca produksi (postproduction)
(Darwanto, 2007).

Tahapan praproduksi merupakan proses awal dari seluruh kegiatan produksi program atau kegiatan yang direncakan dalam sebuah tim kerja. Tahapan ini bermula dengan penggalian ide dan gagasan untuk merancang sebuah program secara keseluruhan. Tahapan produksi merupakan proses berikutnya setelah pada tahap praproduksi sudah menentukan secara pasti hasilnya akan seperti apa, maka di tahapan ini dilakukan eksekusi untuk pelaksanaannya. Tahapan pascaproduksi merupakan proses akhir dengan melakukan penyuntingan dan pemberian efek grafis ataupun audio pendukung.

\section{PEMBAHASAN}

Desa Trangsan dikenal sebagai desa kreatif karena sebagian besar berprofesi menjadi pengrajin rotan. Hasil karyanya pada tahun 2004 telah memasuki pasar internasional. Oleh karena itu, pada tahun 2016, desa tersebut diresmikan sebagai Desa Wisata Rotan. Salah satu kegiatan pendukung lainnya berupa Grebeg Penjalin, sebagaimana dikemukakan oleh Agung Triyanto, Sekretaris Desa Trangsan:
"...sebenarnya sudah lama masyarakat Desa Trangsan memproduksi berbagai kerajinan dari rotan, seperti penjalin, anyaman, kursi, meja, lemari, keranjang, parsel, holahop, bola rotan, dan masih banyak lagi Mas. Barulah tahun 2006 itu baru diresmikan jadi Desa Wisata Rotan Trangsan, melalui agenda tahunan Grebeg Penjalin nah gitu" (Triyanto, 2018).

Realitas-realitas itu potensial untuk dipromosikan dengan media audiovisual 
dengan memberdayakan pemuda karang taruna setempat. Untuk itu diperlukan strategi kreatif bagaimana potensi-potensi tersebut dapat dipublikasikan dan pemuda setempat dapat diberdayakan.

Bahasan ini fokus pada strategi kreatif workshop kepada pemuda karang taruna dalam memproduksi kontain-kontain video seputar peristiwa seni budaya di Desa Trangsan dengan menggunakan media perekaman yang ada termasuk dengan smartphone.

Sesuai dengan metode yang telah disampaikan di atas, maka berikut disampaikan strategi kreatif di setiap tahapan-tahapan produksinya:

\subsection{Strategi Kreatif Tahap Praproduksi}

Pada tahap ini dilakukan workshop tentang pengenalan video kreatif tentang promosi desa wisata. Pemuda karang taruna dikenalkan karya-karya video kreatif agar memiliki imajinasi yang bisa diterapkan di desanya.

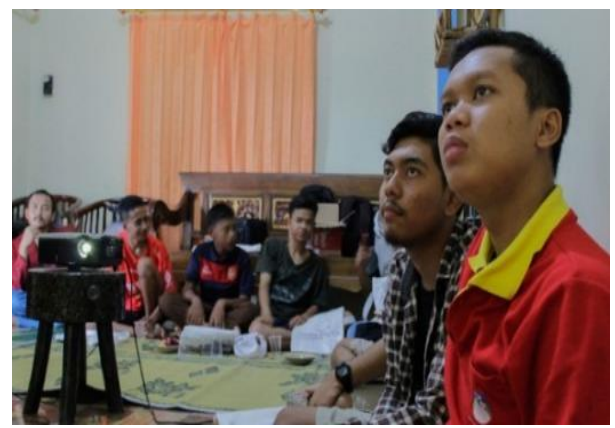

Gambar 1. Praproduksi video pemuda desa Trangsan (Foto: Daniel, 2019)

Para pemuda Desa Trangsan diberikan materi-materi tentang persiapanpersiapan dasar sebelum eksekusi objek- objek pengambilan gambar video di lapangan. Persiapan-persiapan tersebut juga diantaranya persiapan mematangkan konsep konten video serta persiapan perangkat pengambilan gambarnya.

Penerapan strategi kreatif dalam proses produksi video yang digunakan ada untuk tahapan ini adalah pentingnya dalam penentuan ide dan konsep visualisasi yang akan digunakan pada tahap produksi. Pada dasarnya konsep yang dipilih pada tahapan ini dititikberatkan pada konsep yang menguatkan kekhasan atau ikonik dari Desa Wisata Rotan. Penekanan yang diberikan pada pentingnya pemilihan objekobjek pengambilan gambar video yang menekankan pada kekhasan, keunikan dan ikonik dari Desa Wisata Rotan, khususnya yang nantinya akan dipertontonkan pada acara Grebeg Penjalin 2019.

\subsection{Strategi Kreatif Tahap Produksi}

Pada tahap ini para pemuda Desa Trangsna diberi workshop tentang beberapa sudut pengambilan gambar (angle camera) dengan menggunakan smartphone dan tripod.

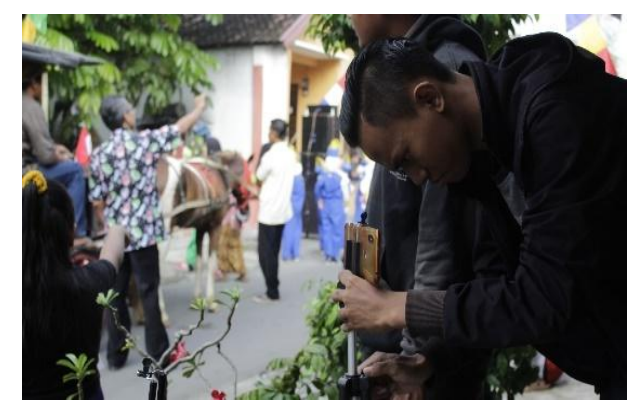

Gambar 2. Kegiatan produksi video pemuda Desa Trangsan (Foto: Daniel, 2019) 
Berikut ini dipaparkan beberapa potongan gambar video (screen shot) hasil pengambilan gambar yang dibuat oleh pemuda Desa Trangsan pada tahapan produksi dengan tema utama yang diangkat adalah acara tahunan Grebeg Penjalin 2019 (tanggal 29 April - 4 Mei 2019) yang dijadikan konten video tentang promosi kekhasan Desa Trangsan.

Produksi video part 1

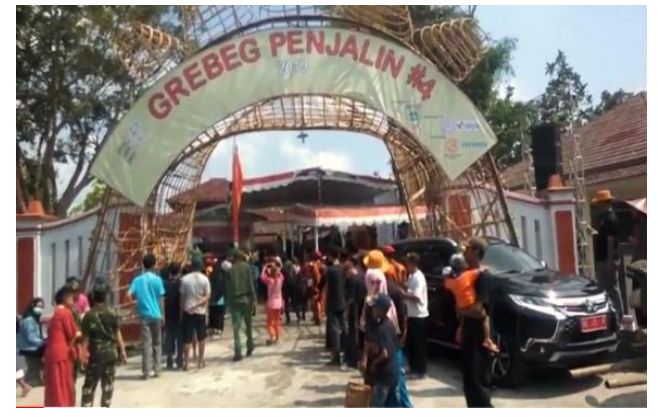

Gambar 3. Tampilan video hasil produksi video part 1 (A), timecode 00:00:09 (Kutipan layar: Daniel, 2019)

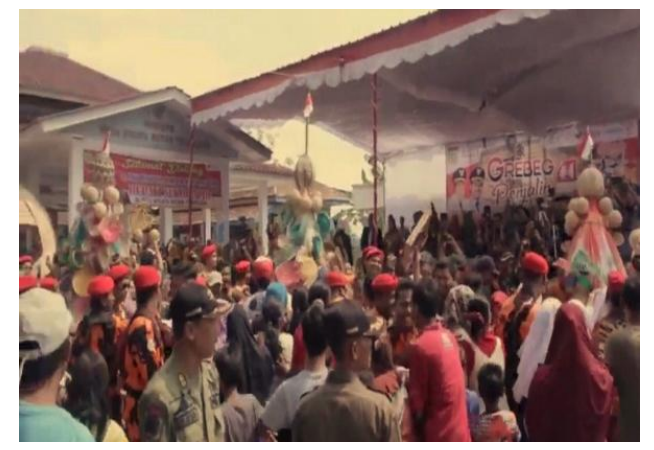

Gambar 4. Tampilan video hasil produksi video part 1 (B), timecode 00:00:13 (Kutipan layar: Daniel, 2019)

Dua gambar dari hasil pengambilan gambar di atas, baik itu potongan Gambar $3(\mathrm{~A})$ atau Gambar 4(B), keduanya berusaha menunjukkan adanya satu kemeriahan suatu acara Grebeg Penjalin. Potongan Gambar 3 (A) menggunakan tipe pengambilan gambar
Long Shot (LS) dengan penyampaian konten dan makna dalam frame gambar tersampaikan karena telah tertera jelas nama acaranya yaitu Grebeg Penjalin. Sedangkan, potongan Gambar 4 (B) merupakan hasil pengambilan gambar dengan Medium Long Shot (MLS). Pada potongan gambar ini dirancang menjadi satu bagian yang memiliki makna pendukung dari potongan Gambar 3 (A), yaitu menunjukkan kemeriahan para pengunjung acara Grebeg Penjalin tersebut.

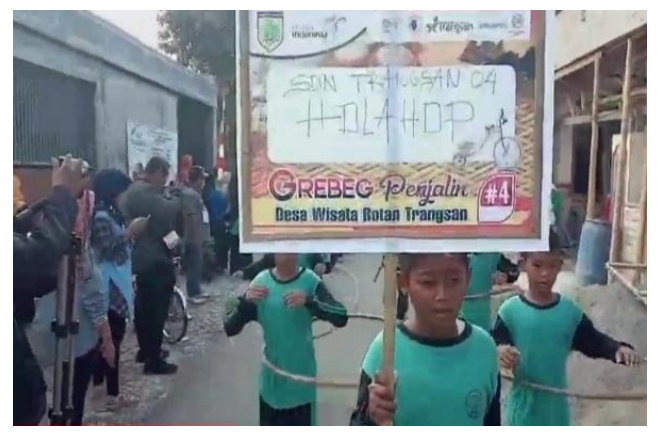

Gambar 5. Tampilan video hasil produksi video part 1 (C), timecode 00:00:51 (Kutipan layar: Daniel, 2019)

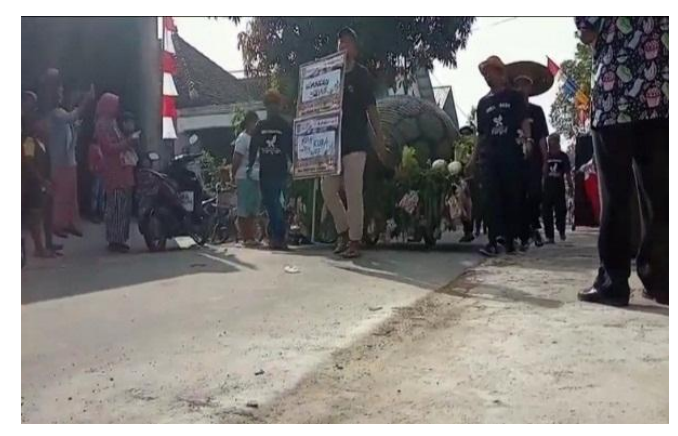

Gambar 6. Tampilan video hasil produksi video part 1 (D), timecode 00:01:00 (Kutipan layar: Daniel, 2019)

Potongan Gambar 5 (C) diambil dengan menggunakan tipe pengambilan gambar Medium Shot (MS) pada rombongan karnaval anak-anak Sekolah Dasar yang membawa papan. Gambar 


\section{CAPTURE}

tersebut yang menunjukkan rombongan yang turut berpartisipasi dalam kemeriahan Grebeg Penjalin. Potongan Gambar 6 (D) masih mengambil objek arak-arakan peserta karnaval di Grebeg Penjalin, akantetapi pengambilan gambarnya lebih bervariasi tipe pengambilan gambarnya, yaitu dengan Low Level Shot (LLS) atau terkadang disebut mata katak (frog eye shot). Dengan tipe pengambilan gambar ini mengesankan objek terlihat lebih jelas dan berkarakter karena terlihat dari bawah mengarah ke bagian atas.

Empat frame potongan gambar hasil produksi pemuda Desa Trangsan di atas telah menunjukkan intensitas dan kreativitasnya untuk mengangkat dan mempromosikan Desa Wisata Rotan Trangsan melalui konten-konten videonya.

\section{Produksi video part 2}

Dua frame potongan Gambar 7 (A) atau Gambar 8 (B) menunjukkan salah satu penampilan peserta karnaval Grebeg Penjalin lengkap dengan kostum busananya yang mayoritas terbuat dari bahan penjalin atau rotan. Gambar 7 (A) diambil dengan pengambilan gambar tipe Full Shot (FS) yang menyampaikan pesan tentang gambaran totalitas dua peserta karnaval Grebeg Penjalin dengan kostum busananya yang menarik. Sedangkan Gambar 8 (B) diambil dengan tipe pengambilan gambar relatif Medium Close Up (MCU), yang memberi kesan yang mendalam tentang ekspresi lepas dan ceria salah satu peserta karnaval yng lengkap dengan kostum busananya yang terbuat dari bahan penjalin atau rotan.

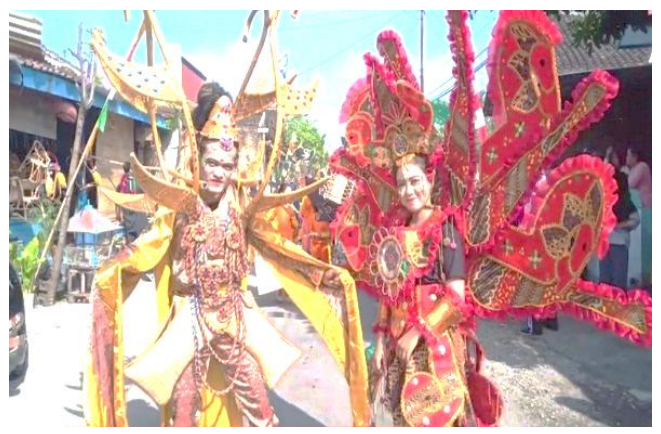

Gambar 7. Tampilan video hasil produksi part $2(\mathrm{~A})$, timecode 00:00:08 (Kutipan layar: Daniel, 2019)

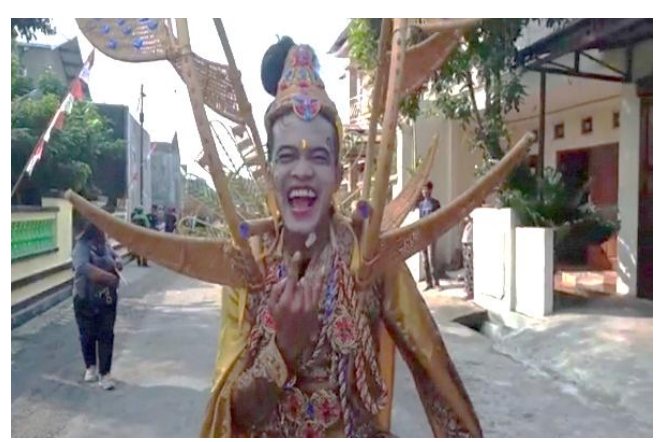

Gambar 8. Tampilan video hasil produksi part 2 (B), timecode 00:00:37 (Kutipan layar: Daniel, 2019)

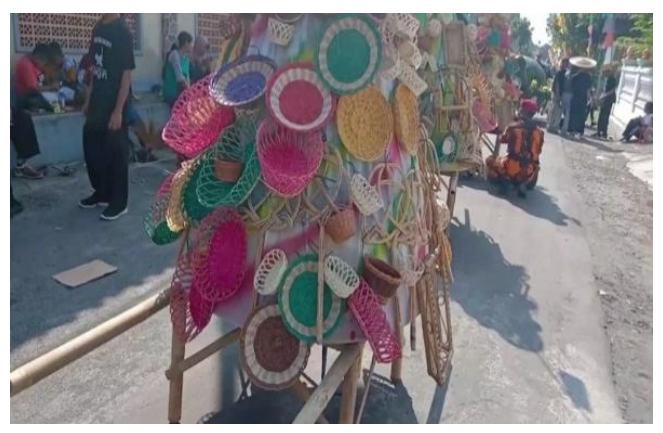

Gambar 9. Tampilan video hasil produksi part 2 (C), timecode 00:01:46 (Kutipan layar: Daniel, 2019)

Gambar 9 (C) menggunakan tipe pengambilan gambar Full Shot (FS) dari belakang objek, yang menggambarkan tampilan peserta karnaval Grebeg Penjalin lengkap dengan pernak-pernik hasil kerajinan tangan yang terbuat dari bahan 
penjalin atau rotan dan diberi aksen warnawarna terang yang beragam supaya lebih menarik perhatian penonton.

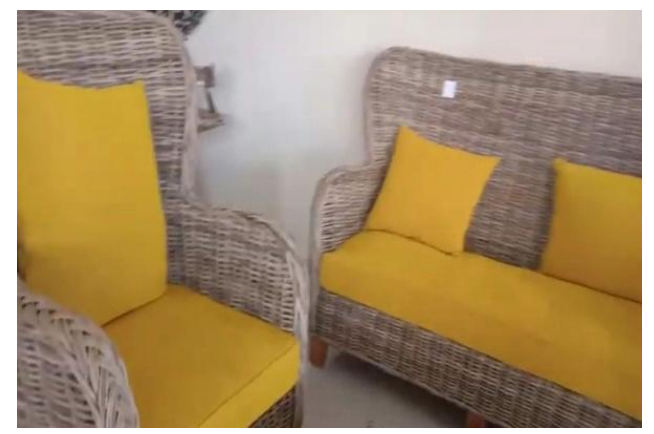

Gambar 10. Tampilan video hasil produksi part 2 (D), timecode 00:01:57 (Kutipan layar: Daniel, 2019)

Gambar 10 (D) dihasilkan dengan tipe pengambilan gambar Medium Shot (MS) lurus sesuai dengan mata memandang (straight shot). Gambar ini menyampaikan pesan tentang salah satu contoh bentuk mebeler yaitu satu set kursi tamu yang semuanya terbuat dari bahan penjalin atau rotan asli produk unggulan desa setempat.

Potongan-potongan gambar hasil produksi part 2 di atas merupakan karya video yang pemuda Desa Trangsan, dengan harapan agar eksistensi Desa Wisata Rotan terangkat kembali melalui publikasi di media sosial dan Youtube. Selain itu, keberadaan smartphone pun di tangan pemuda desa akan lebih bermanfaat dan dimaksimalkan kegunaannya.

Penerapan strategi kreatif dalam tahap produksi video ini menekankan pentingnya pemilihan pengambilan gambar dengan tipe shot-shot yang dapat memaksimalkan kondisi objek, seperti Full Shot (FS), Medium Shot (MS), dan Medium Close Up (MCU). Dengan didukung penempatan sudut pengambilan gambar (camera angle) dan pergerakan pengambilan gambar (camera movement) yang dinamis, maka pemilihan tipe shotshot akan lebih enak dilihat dan kontinuitasnya logis. Sesuai dengan perencanaan strategi pada tahapan praproduksi maka pemilihan objek-objek pada tahap produksi ini juga mengutamakan objek yang menampilkan kekhasan (ikonik) dari objek tersebut, seperti barang atau kostum karnaval yang terbuat dari penjalin atau rotan.

\subsection{Strategi Kreatif Tahap Pasca- produksi}

Penerapan strategi kreatif pada tahap penyuntingan ini yaitu menggabungkan video yang sudah didapatkan dari tahap sebelumnya, dengan menambahkan ilustrasi audio seperti audio atmosfer asli di lokasi ditambah ilustrasi audio lainnya serta informasi tulisan dan gambar yang ikonik dengan acara Grebeg Penjalin. Setelah proses penyuntingan selesai dilanjutkan dengan proses rendering untuk menjadikannya berformat mp4, kemudian dilakukan proses pengunggahan melalui media sosial yang cukup popular di masyarakat, yaitu Youtube dan Instagram. 


\section{CAPTURE}

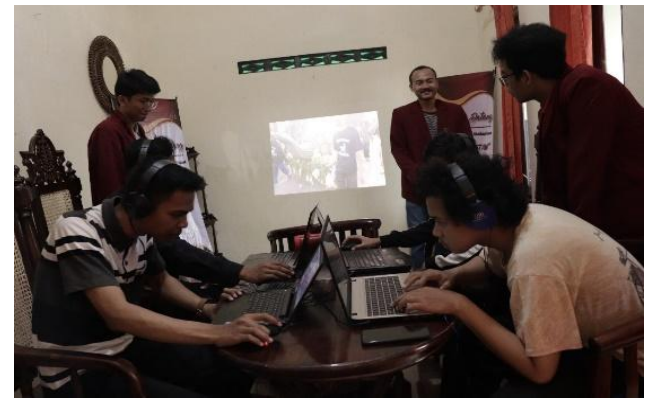

Gambar 11. Pascaproduksi viedeo kreatif pemuda Desa Trangsan (Foto: Daniel, 2019)

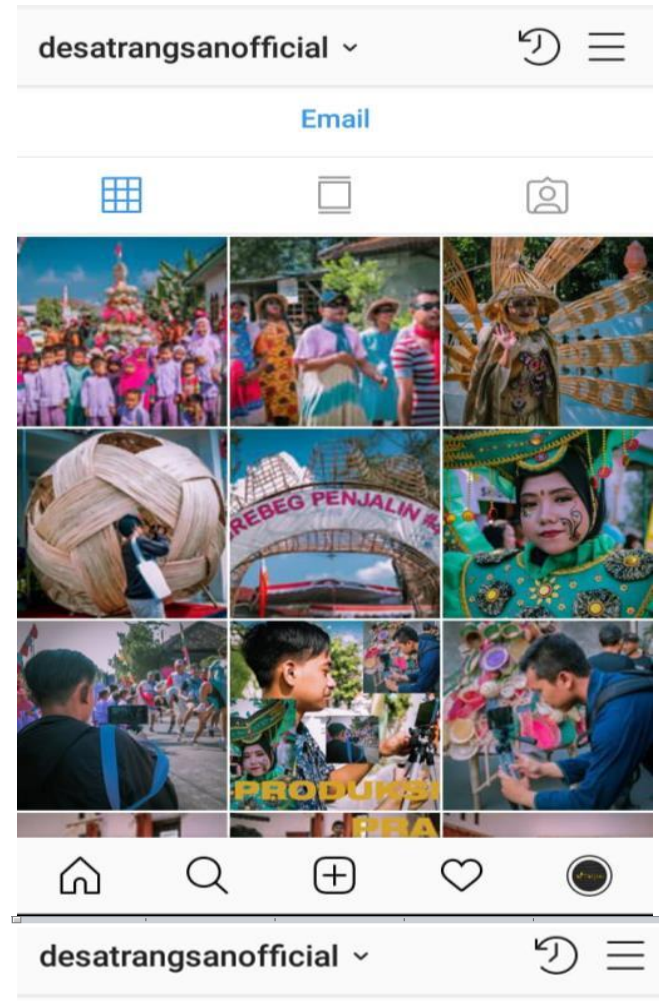

$\mathbf{2 1}$ kunjungan profil dalam 7 hari terakhir

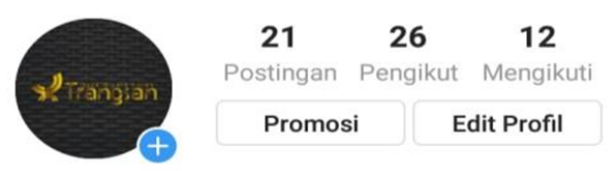

desa trangsan official

Situs Web Daerah

Desa pengrajin rotan kualitas internasional

Official youtube

youtu.be/mpdGkmrBOXg

Gambar 12. Kanal Youtube yang berisi video pemuda Desa Wisata Rotan Trangsan.

(Kutipan layar: Daniel, 2019)

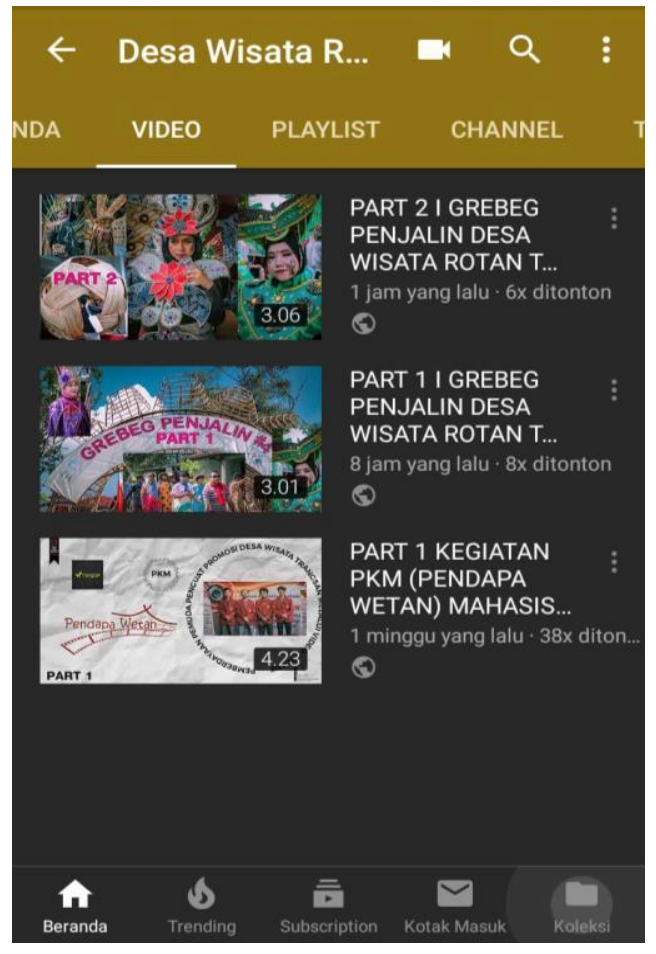

Gambar 13. Layar Instagram yang berisi video pemuda Desa Wisata Rotan Trangsan (Kutipan layar: Daniel, 2019)

\section{SIMPULAN}

Partisipasi masyarakat merupakan modal penting dalam pengembangan sebuah desa wisata. Pengembangan wisata sebagai pengejawantahan dari konsep pariwisata inti rakyat yang mengandung arti bahwa masyarakat desa memperoleh manfaat sebesar-besarnya dalam pengembangan pariwisata.

$$
\text { Kegiatan penelitian ini pada }
$$
dasarnya mengaplikasikan kompetensi bidang ilmu bidang televisi dan film ke dalam bentuk workshop atau pendampingan bersama dalam hal produksi video tentang desa wisata kepada pemuda karang taruna Desa Trangsan. Pemuda karang taruna Susilo 


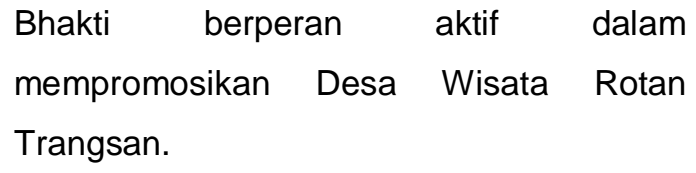

Penerapan strategi promosi yang digunakan dalam kegiatan ini adalah pembuatan konten-konten video dengan menggunakan teknologi audiovisual di smartphone. Strategi yang dilakukan oleh para pemuda Desa Trangsan ini dalam upaya membantu dan menguatkan promosi Desa Wisata Rotan. Promosi dilakukan melalui media sosial yang familiar saat ini Youtube dan Instagram, karena mudah pengaksesannya melalui smartphone.

Strategi produksi video ini menggunakan tiga tahapan sebagai fondasi, yaitu praproduksi, produksi, dan pascaproduksi. Penerapan strategi dalam tahapan praproduksi dapat dimulai dari pentingnya dalam penentuan ide dan konsep yang menjadi tema utama. Konsep yang dipilih mentitikberatkan pada hal-hal yang menguatkan kekhasan atau ikonik dari Desa Wisata Rotan Trangsan.

Pada tahapan produksi, strategi yang perlu diperhatikan adalah pemahaman tentang beberapa tipe pengambilan gambar terhadap objek-objek yang telah direncanakan di tahapan sebelumnya. Penyelarasan akhir dilakukan pada tahap pascaproduksi, yaitu penyuntingan gambar dengan penambahan dan penggabungan unsurunsur ilustrasi audio dan tulisan.

\section{DAFTAR ACUAN}

Darwanto. (2007). Televisi sebagai Media Pendidikan. Yogyakarta: Pustaka Pelajar.

Deparnas. (2005). Renstra Pembangunan Desa Wisata dan Pariwisata Nasional tahun 2005-2009. Departemen Pariwisata.

Rahayu, S., \& Sugihartono, R. A. (2018). Strategi Program Hard News Kompas TV. CAPTURE: Jurnal Seni Media Rekam, 9(2).

Ri'aeni, I. (2015). Penggunaan New Media dalam Promosi Pariwisata Daerah Situs Cagar Budaya di Indonesia. Jurnal Komunikasi, 9(2).

Salim, P., \& Salim, Y. (1993). Kamus Bahasa Indonesia Kontemporer. Jakarta: Modern English Press.

Suyanti, D. W. (2013). Potensi Desa Melalui Pariwisata Pedesaan. Jurnal Ekonomi Dan Bisnis, 12(1).

Triyanto, A. (2018). 41 tahun, Sekretaris Desa Trangsan,Gatak, Sukoharjo, Jawa Tengah.

Yuty, O. A. (1997). Perencanaan dan Pengembangan

Pariwisata. Jakarta: Pradnya Paramita. 